\title{
Konaklama İşletmelerinde Kat Hizmetleri Çalışanlarının Hizmet İçi Eğitim Kalite Algısı ile Motivasyon Düzeyleri Arasındaki İlişki: İstanbul Bölgesinde Bir Araştırma
}

\author{
Doç. Dr. Haluk TANRIVERDi \\ İstanbul Üniversitesi, İktisat Fakültesi, Turizm İsletmeciliği Bölümü, ISTANBUL \\ Araș. Gör. Mehmet Altuğ ŞAHIN \\ İstanbul Üniversitesi, İktisat Fakültesi, Turizm İsletmeciliği Bölümü, İSTANBUL
}

\begin{abstract}
$\ddot{O Z E T}$
Günümüzde gelişmekte olan rekabet koşullarına karşı bir değer yaratmak adına inovatif girişimlerde bulunan konaklama işletmeleri; çalışanlarının motivasyon seviyelerinin artırlmasıla, hizmette verimlilik ve kalite düzeylerinin yükseltilebildiğinin farkına varmışlar ve hizmet içi eğitim tekniklerini bu kapsamda uygulamaya başlamışlardır. Araştırmamızda İstanbul ilinde yer almakta olan ve hizmet içi eğitimin verilmekte olduğu konaklama işletmelerinde kat hizmetleri departmanında çalışan personelin, hizmet içi eğitim kalite algısı ile işin kendisi ile ilgili motivasyon unsurları ve iş dışı motivasyon unsurları arasındaki ilişki, ayrıca bu ilişkinin gücü incelenmektedir. Hizmet içi eğitimin verilmekte olduğu saptanan iki adet konaklama işletmesinde 110 çalışana anket uygulanmış; hizmet içi eğitim kalite algısı ölçeği ile işin kendisi ile ilgili ve iş dışı motivasyon unsurları ölçekleri kullanılmıştır. Elde edilen veriler faktör, korelasyon ve regresyon analizleri ile değerlendirilmiştir. Araştırma sonucunda ise hizmet içi eğitim kalite algısı ile işin kendisi ile ilgili motivasyon unsurları ve iş dışı motivasyon unsurları arasında doğrusal bir iliş̧ki bulunduğu saptanmıştır.
\end{abstract}

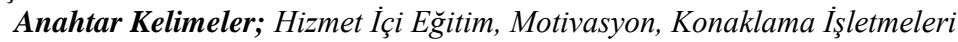

JEL Sinıflaması: L83, O15

\section{Relationship Between In-Service Training Quality Perception and Motivation Factors of Hospitality Businesses Housekeeping Employees: A Research In Istanbul Area}

ABSTRACT

Hospitality businesses that establish innovative initiatives in order to create a value against competitive conditions that occur today, started implementing in-service training techniques by concluding the fact that an increase in motivations of employees result in a linear improvement in productivity and quality in services. In our survey, we examined the relationship and its power between in-service training and intrinsic job motivational factors and also between in-service training and extrinsic job motivational factors in hospitality businesses that apply in-service training programs in Istanbul area. Surveys were conducted on 110 housekeeping employees of two hospitality businesses'; scales of in-service training quality perception, intrinsic job motivational factors and extrinsic job motivational factors are being used. Data that was collected by this sample are analyzed by factor, correlation and regression analysis. Within the framework of the research it is concluded that there is a linear relationship between in-service training and intrinsic job motivational factors and also between in-service training and extrinsic job motivational factors.

Key Words; In-Service Training, Motivation, Hospitality Businesses

JEL Classification: L83, O15 


\section{Giriş}

Gelişmekte olan rekabet ortamında işletmeler açısından, hem iç hem de dış müşterilerin motivasyon düzeyleri önemli konular olarak ön plana çıkmaktadır. Öncelikle iç müşteri olarak gruplandırılan işletme bünyesinde yer alan çalışanların motive edilmesi ile dış müşterilerde tatmin duygusu yaratılabileceği bir gerçektir.

Emek yoğun bir sektör olarak karşımıza çıkmakta olan konaklama endüstrisinde, iş gücünün motivasyonunun sağlanması ile verimlilik ve kalite düzeylerinde artışlar gözlemlenmektedir. Çalışanların motive edilmesinde ise eğitim faktörleri rol oynamakta; gerçekleştirilen hizmet içi eğitimler birer belirleyici olmaktadır.

Hizmet içi eğitimin motivasyon ile bir ilişkisi olup olmadı̆̆ı; ilişkinin mevcut olması durumunda ise gücünün belirlenmesi amacı ile gerçekleştirilen bu çalışma; turizm endüstrisinin önem arz eden kollarından birini oluşturan konaklama işletmelerinde gerçekleştirilmiştir. İstanbul bölgesinden seçilmiş olan iki adet konaklama işletmesinde anketler yapılmış olup, daha önceden hizmet içi eğitim almış olan kat hizmetleri departmanı çalışanlarının, hizmet içi eğitim kalite algısı ile motivasyon düzeylerine ait ilişki aranmıştır.

Gerçekleştirilen çalışma dört temel bölümden ve sonuçtan oluşmakta olup, ilk bölümde hizmet içi eğitim ve kapsamından bahsedilmiştir. İkinci bölümde motivasyon ve Herzberg'in Çift Faktör Teorisi'nden bahsedilmiş olup; üçüncü bölümde ise hizmet içi eğitim ile motivasyon arasındaki ilişki ile alakalı literatür taraması gerçekleştirilmiştir. Dördüncü bölümde ise hizmet içi eğitimin verildiği saptanan, İstanbul ilinde iki farklı konaklama işletmesinde gerçekleştirilmiş olan çalışmanın bulguları yer almaktadır. Sonuç bölümünde ise araştırmaya ait ulaşılan sonuçlar ve kısıtlamalardan bahsedilmektedir.

\section{Hizmet İçi Eğitim ve Kapsamı}

Bir işletmede çalışan kişilerin işini etkili bir şekilde gerçekleştirebilme yeteneği, çalışanın beceri seviyesi, etkili eğitimlerin varlığı, verilen görevlerin gerçekleştirilmesinde kullanılacak olan araçlara ulaşılabilirliğinden etkilenmektedir (Hayes ve Ninemeier, 2008: 71). Bu kapsamda ileride müşteriler tarafindan değer biçilecek olan yeni hizmetlerin sağladığı çıktıların, arzulanan gereklilik seviyesinde olabilmesi için hizmet işletmelerinde İnsan Kaynakları Yönetimi'nin eğitime yapacağ 1 yatırımlar önem arz etmektedir (Ottenbacher, 2008: 422).

Yeni şeylerin öğrenilmesi veya bilgilerin hatırlanması amacı ile geliştirilebilecek eğitim ve geliştirme programları ile çabaları (Aksu, 2005: 947); verimliliğin, kalitenin ve sorumlulukların sağlanabilmesinde, işletmelerin rekabetçi ortamlarda yaşamlarını sürdürmeleri ve rekabet edebilmeleri açısından yarar sağlayıcı amaçlar içermektedirler (Nickson, 2007: 142). Bu kapsamda hem başarının sağlanabilmesi, hem de verimliliğin artırılması ile çalışanların motive edilmesinde hizmet içi eğitim uygulamaları önem arz etmektedirler (Pehlivan, 1997: 120). 
Hizmet içi eğitim hem ürün üretiminde, hem de hizmetlerde verimlilik sağlanması ve daha kaliteli çıktıların alınması açısından ön plana çıkmaktadır (Aytaç, 2000). Ayrıca hizmet içi eğitim, üretim süreçlerinde ortaya çıkma ihtimali bulunan hataların ve kazaların en az seviyeye indirilerek maliyetlerin azaltılması ve kârlılı̆̆ın yükseltilmesi, ürün sunumunun iyileştirilmesi ve geliştirilmesi amaçlarına dayanan; işletme bünyelerinde bulunan işgücünün bilgi, beceri ve davranış düzeylerini yükseltici, süreklilik arz eden planlı eğitim etkinlikleridir (Sezgin ve Ünlüölen, 2011: 4).

Hizmet içi eğitim, işletme bünyesinde yer almakta olan bütün kademe çalışanlarına uygulanması zorunlu bir eğitim sürecidir. Hizmet içi eğitimin amaçlarının belirlenmesinde ise işletme ve çalışanların eğitim gerekliliklerinin doğru saptanması temel öğe olarak yer almaktadır (Pehlivan, 1997: 106-108).

Hizmet içi eğitimlerin uygulanmasında, eğitim planları ve yıllık programlara göre sistemler belirlenmelidir. Belirlenmiş olan hizmet içi eğitimi uygulamaları, örgüt içi ve örgüt dışı eğitim uygulamaları olmak üzere ikiye ayrılmaktadırlar. Personelde sürekli bir gelişimin sağlanması amacı ile gerçekleştirilen hizmet içi eğitim uygulamalarında başarının sağlanabilmesi adına, çalışanlarında bu süreçte yeterli motivasyonu göstermeleri gerekmektedir. Uygulamalar ile ilgili olarak ise, sürekli bir geri besleme sistemi kurulmal1, böylece eğitimin başarısı ve gerekli iyileştirmelerin sağlanabilmesi adına işletmelerde gereksinimlerin doğru belirlenmesi sağlanmalıdır (Bilgin vd., 2007: 24).

Ayrıca hizmet içi eğitim, iş başında eğitim ve iş dışında eğitim olmak üzere de ikiye ayrılabildiği gibi (Pehlivan, 1997: 114); eğitim teknikleri, hedef kitleler açısından da gruplanabilmektedir. Bu gruplar ve teknikler ; büyük gruplar (düz anlatım, forum), küçük gruplar (seminer, kurs, komite veya tartışma grubu ve benzerleri), seçilmiş gruplar (konferans, yuvarlak masa, atölyeler), bireyler (ödevler, bireysel projeler, stajyerlik ve benzerleri) ve diğer gruplardan (örnek olay, rol oynama, teknik geziler) oluşmaktadır (Bilgin vd., 2007: 17-18).

Konaklama işletmelerinin uygulamakta oldukları eğitim programlarının etkinliğini etkileyen unsurlar; eğitimi alan kişilerin geçmişi, verilmekte olan eğitim programlarının kalitesi, eğitim programlarının göreceli esnekliği, katlanılmakta olunan maliyetler ve hem etkinlik hem de maliyetlerin takip edilmeye çalışılması maddelerinden oluşturmaktadır (Harris, 1995: 25). Geliştirilecek ve uygulanacak olan programlar bu unsurlar göz önünde bulundurularak hazırlanmalı; hizmet içi eğitimler ise bu çerçevede sürekli eğitimin bir parçası olarak programlara entegre edilmelidir.

Konaklama işletmelerinde verilecek olan hizmet içi eğitimler, işletme ihtiyaçlarına göre önceden saptanarak sistemli bir şekilde planlanmış olarak verilmediği takdirde, işletme bünyesinde sorunlara neden olabilmektedir. $\mathrm{Bu}$ kapsamda, hizmet içi eğitim sürecinin kapsamlı ve uzun bir süreç olarak değerlendirilmesi gerekmektedir (Uslu vd., 2013: 114). Ayrica unutulmamas1 gereken bir konu da, önemli işletme politikalarının oryantasyonlar ile çalışanlara anlatılabileceği; ancak diğer işletme politikalarının ise hizmet içi eğitim 
programları sayesinde kişilere aktarılabileceğidir (Hayes ve Ninemeier, 2008: 153).

Aksu'nun (2005) otel işletmelerinde hem yöneticiler hem de çalışanların eğitim ihtiyaçlarının tanımlanmasına dair yapmış olduğu çalışmaya göre, her iki grubun da ortak olarak eğitim almayı arzuladıkları konular; örgütsel yapı, yönetim ve organizasyon, iletişim, motivasyon, muhasebe-bütçeleme ve yabanc1 diller başlıklarından oluşmaktadır. Ayrıca yöneticilerin mevcut bilgi ve becerilerini geliştirmeye yönelik eğitimleri tercih edildiği gözlemlenmiştir.

Korkmaz ve diğerlerinin (2010) yapmış oldukları çalışma kapsamında turizm sektöründe çalışmakta olan profesyonel turist rehberlerinin hizmet içi eğitim seminerlerine katılımının sağlanması ile pazarlamayla ilgili davranışlarda pozitif bir etki yaratmasının olası olduğu belirtilmiştir. Ancak uygulanmakta olan pazarlama karmasının ve hem iç hem de dış paydaşların istek ile önerileri dikkate alınarak, bu seminerlerin yeterli seviyeye getirilmesine de dikkat çekilmektedir.

\section{Motivasyon ve Herzberg'in Çift Kavram Teorisi}

İşletmelerin başarılı olabilmesi için, gerekli olan faktörlerden birisi de motive edilmiş çalışanlardır. $\mathrm{Bu}$ yüzden işverenlerin çalışanlarını motive edebilmesi konusu, işletmelerin pazarlarda başarı sağlamasını olası kılmaktadır. Hem çalışanların kendini motive hissedebileceği, hem de işletme amaçlarına ulaşılabilmesi adına kişilerin yönlendirildiği bir ortamın geliştirilmesi; yöneticiler açısından sıkıntılar yaratan konular olarak ön plana çıkmaktadır (Lundberg vd., 2009: 890-891). İşletmelerin başarıya ulaşmasında önemli rol oynamakta olan çalışanların, çalışma ortamlarında iş tatmini sağlayabilmeleri adına gerekli motivasyon araçları saptanmalı ve geliştirilmelidir (Öztürk ve Alkış, 2011: 454).

Globalleşme, teknolojik gelişmeler ve kültürel farklılıklar gibi dışsal faktörlerden etkilenmekte olan konaklama endüstrisi, geleneksel reaktif yaklaşımdan daha çok gelişme gösteren proaktif bir yaklaşım sergileme yönünde seyir etmektedir. Artık daha karmaşık değişimler göstermekte olan çevreden ötürü, çalışanların da becerilerini geliştirmeleri gerekmektedir. Ancak geleneksel yaklaşımın günümüze bırakmış olduğu ve engel teşkil eden konular mevcudiyetini korumaktadır. Daha üst seviyelerde beceriler geliştirilebilmesi adına, öncelikli olarak geleneksel yaklaşım kaynaklı sorunlar giderilmelidir. Bu kapsamda ise iletişim becerileri, davranışlar ve motivasyon, üzerinde çalışılması gereken olgular olarak ön plana çıkmaktadırlar (Whiltelaw vd., 2009: 17).

Motivasyon ve bunu etkileyen faktörlerin tanımlanmasında birçok teori üretilmiş olup; bunlar içinde halen geçerliliğini devam ettirmekte olan ve Frederick Herzberg tarafindan geliştirilen Çift Faktör Teorisi bulunmaktadır. Davranış bilimci Frederick Herzberg'in önermiş olduğu teoriye göre, çalışma davranışlarını ve motivasyonlarını etkilemekte olan iki bağımsız faktör seti bulunmaktadır (Boella ve Goss-Truner, 2005: 31). Bunlardan ilki olan hijyen faktörleri, çalışanlar arasında memnuniyetsizliğe sebep olmaktadır. Bu faktörlerin yoklukları iş performansını etkilemektedir (Hayes ve Ninemeier, 2008: 73). Tatmin edici seviyelerde tutulmamas durumlarında negatif motivasyon ortaya çıkmaktadır, ancak tatmin edilmesi durumlarında ise kişiyi motive 
etmemektedirler (Walker ve Miller, 2010: 184). Hijyen faktörleri şunlardan oluşmaktadır; örgüt politikası ve idari stil, fiziksel çalışma koşulları, ücret, iş güvencesi, kişiler arası ilişkiler, yönetici davranışları (Aktaş, 2002: 194; Boella ve Goss-Truner, 2005: 28).

Diğer faktörler seti ise motivasyon faktörleridir. Bu faktörlerin varlığı çalışanların işleri hakkında pozitif düşünceler barındırmasını sağlar. İşgücünün motive edilebilmesi adına motivasyon faktörleri işin bünyesinde oluşturulmalıdır (Boella ve Goss-Truner, 2005: 32). Bu faktörler performansların olumlu etkilenmesinde ana rolü oynamaktadırlar (Hayes ve Ninemeier, 2008: 73). Motivasyon faktörlerini; başarı, takdir edilme, işin içeriği, ilerleme ve gelişme imkânları, sosyal statü ve sorumluluk oluşturmaktadır. İdeal olarak her iki faktör setinin de aynı anda uygulamaya konulması gerekmektedir (Aktaş, 2002: 194; Boella ve Goss-Truner, 2005: 28-32).

\section{İlişkisi}

III. Konaklama İşletmelerinde Hizmet İçi Eğitim ve Motivasyon

Gelişmekte olan rekabet koşulları çerçevesinde, üretim faktörlerinden biri olarak ön plana çıkan işgücüne daha yüksek seviyelerde vasıf kazandırılması adına, işletmeler hizmet içi eğitimi uygulamaları gerçekleştirmektedirler. Çalışanlarda verimlilik artırılması ve motivasyon yaratılması adına hizmet içi eğitim uygulamaları gereklilik göstermektedir (Öztürk ve Sancak, 2007: 762). Hizmet içi eğitim faaliyetleri sayesinde konaklama işletmeleri bünyesinde işgücüne ait eksikliklerin giderilmesi amaçlanmakta; böylece çalışanlara kazandırılacak olan teknik, teorik ve pratik beceriler ile hem işletme verimliliği ve kalite avantajı sağlanması, hem de çalışanların motivasyonlarının yükseltilmesi ve iş tatminin sağlanabilmesi olası kılınmaktadır (Akınc1, 2002: 5; Uslu vd., 2013: 102).

Konaklama işletmelerinde çalışanların işletmeye bağlılıklarının artırılması açısından motivasyon önem arz etmekte; ayrıca kalitenin istenen seviyede sağlanabilmesi için işgücü eksikliklerinin saptanarak gerekli ve süreklilik arz eden eğitimlerin verilmesi gerekmektedir (Öztürk ve Seyhan, 2005: 138). Yapılan araştırmalar kapsamında personelin eğitilmesi, turizm sektöründe gerçekleştirilecek inovasyon çalışmalarının başarıya ulaşabilmesi adına önem arz eden dört İnsan Kaynakları Yönetimi uygulamasından biri olarak sayılmaktadır (Ottenbacher, 2008: 420).

Konaklama işletmelerinde Akıncı'nın (2002) yapmış olduğu çalışma sonucunda psiko-sosyal faktörlerin çalışanların iş tatmini üzerinde etkisi olduğunu ortaya konmuş; çalışanların kendini geliştirmesi ve iyileştirmesi konusunda ise hizmet içi eğitimin rolünün önem arz ettiğinden bahsedilmiştir. Kişilerin iş tatmini sağlamasında hizmet içi eğitimin etkinliğinden bahsedilen çalışmada ayrıca hizmet içi eğitim sayesinde işletmelerde ekip ruhunun gelişmesine yardımcı olacağı belirtilmiştir.

Uslu ve diğerleri (2013) yapmış oldukları çalışmada hizmet içi eğitimin verimliliği olumlu yönde etkilediği faktörleri sayarken; çalışan güveninin artması, iş bilincinin sağlanması, çalışan ufkunun açılması gibi motivasyon ile ilgili 

Algısı ile Motivasyon Düzeyleri Arasındaki İlişki: Istanbul Bölgesinde Bir Araştırma bağlantısının da bulunduğunu belli eden maddeler sıralamışlardır. Öztürk ve Alkış (2011) yapmış oldukları çalışma kapsamında ise konaklama işletmelerinde çalışan motivasyonunu etkileyen faktörlerden, eğitimin düşük seviyede bulunduğunu, bu sebepten ötürü motivasyon artırıcı ve kalite yükseltici etkisi olan hizmet içi eğitimlerin uygulamaya konulması konusuna dikkat çekmişlerdir.

Lundberg ve diğerlerinin (2009: 896) konaklama işletmelerinde sezonluk çalışanların motivasyonları ile ilgili yapmış olduğu çalışmada, Herzberg'in Çift Faktör Teorisi kullanılmış ve sonuç olarak bu kuramın hâlâ geçerliliğinin olduğu belirtilmiştir. Ayrıca yapılan farklı bir çalışmada, konaklama işletmelerinde Herzberg tarafindan öne sürülmüş olan hijyen faktörlerinin birer motivasyon arac1 olarak yer aldığ 1 kanısına çalışma sonuçlarında ulaşılmıştır. Fakat Herzberg'in belirlemiş olduğu motivasyon faktörlerinin, hijyen faktörlerine nazaran iş tatmini üzerinde daha büyük bir etki yarattı̆g 1 da belirtilmektedir (Alkış ve Öztürk, 2009: 230).

Sezgin ve Ünlüönen'in (2011: 13) mutfak personeli üzerine yapmış oldukları çalışma kapsamında ise hizmet içi eğitimin, işyerine duygusal bağlılık ve iş yerindeki tatmin düzeylerinde artışa sebep olduğu sonucuna ulaşmışlardır. Ayrıca verilecek olan hizmet içi eğitimin gerekliliğini ve belirlenmiş ihtiyaçlara göre sistemli bir şekilde verilmesi gerektiğini vurgulamışlardır. Bu çalışmada, işin kendisi ile ve iş dışı motivasyon unsurlarının düzeylerini belirleyebilmek ve olası hizmet içi eğitim algısı ile ilişkisini belirleyebilmek için Herzberg'in Çift Faktör Teorisine ilişkin bilgilerin test edilmesi amaçlanmıştır.

\section{Araştırmanın Yöntemi ve Bulguları}

\section{A. Araştırmanın Amacı ve Hipotezleri}

Araştırmada kapsamında, çalışanların hizmet içi eğitim kalite algısı ile işin kendisi ile ilgili olan motivasyon unsurları ve iş dışı motivasyon unsurları kaynaklı motivasyon düzeyleri arasında anlamlı bir ilişkinin araştırılması; ayrıca ilişki gücünün ortaya konulması amaçlanmaktadır. Bu kapsamda geliştirilmiş olan hipotezler şöyledir;

$\mathrm{H}_{0}$ : Çalışanların hizmet içi eğitim kalite algısı ile işin kendisi ile ilgili olan motivasyon unsurları kaynaklı motivasyon düzeyleri arasında anlamlı bir ilişki bulunmamaktadır.

$\mathrm{H}_{1}$ : Çalışanların hizmet içi eğitim kalite algısı ile işin kendisi ile ilgili olan motivasyon unsurları kaynaklı motivasyon düzeyleri arasında anlamlı bir ilişki bulunmaktadır.

$\mathrm{H}_{0}$ : Çalışanların hizmet içi eğitim kalite algısı ile iş dışı motivasyon unsuları kaynaklı motivasyon düzeyleri arasında anlamlı bir ilişki bulunmamaktadır.

$\mathrm{H}_{2}$ : Çalışanların hizmet içi eğitim kalite algısı ile iş dışı motivasyon unsuları kaynaklı motivasyon düzeyleri arasında anlamlı bir ilişki bulunmaktadır.

\section{B. Evren ve Örneklem}

Araştırmanın evrenini İstanbul ilinde faaliyet göstermekte olan ve hizmet içi eğitimin verildiği gerçekleştirilen görüşmeler sonrasında saptanan, İstanbul bölgesindeki beş yıldızlı konaklama işletmelerinin kat hizmetleri bölümü 
çalışanları oluşturmaktadır. Kolayda örnekleme yoluyla oluşturulan örneklem grubu; İstanbul Bölgesi'nde bulunan iki adet beş yıldızlı konaklama işletmesinde hizmet içi eğitim almış çalışan ve anket uygulamayı kabul etmiş olan 18 şef, 36 idari personel ve 56 kat hizmetleri bölümü olmak üzere toplam 110 personelden oluşmaktadır. Bu kapsamda örneklemde yer almakta olan çalışanların hepsine yüz yüze görüşmelerle anket uygulanmıştır. Yapılan değerlendirme sonucu geri dönen anketlerin tümü analiz yapmak için uygun bulunmuştur. Çalışma kapsamında elde edilen veriler zaman kısıtı sebebiyle İstanbul il merkezindeki otellerden elde edilmiştir.

\section{Veri Toplama Araçları}

Araştırmada veriler 3 bölümden oluşan anket yöntemiyle toplanmıştır. Anketin birinci bölümünde katılımcıların yaş, cinsiyet, çalışma yılı, görevleri, hizmet içi eğitim sayısı ve hizmet içi eğitimin türü soruları yöneltilmiştir. İkinci bölümünde ise hizmet içi eğitim kalite algısı ölçeği ve üçüncü bölümünde ise işin kendisi ile ilgili motivasyon unsuları ve iş dışı motivasyon unsularından oluşan motivasyon ölçeği yer almaktadır. Ölçeklere ilişkin bilgilere aşağıda yer verilmektedir.

Araştırmada kullanılan hizmet içi eğitim kalite algısı ölçeği Clemenz'e (2001) ait "Measuring Perceived Quality of Training in the Hospitality Industry" isimli doktora tezinden alınmıştır. Ölçek İngilizceden Türkçeye çevrilerek kullanılmış olup; ölçekte yer alan ifadeler 5'li Likert ölçeğine göre yerleştirilmiş 30 sorudan oluşmaktadır. Ölçeğe ait çeviri tarafımızca gerçekleştirilmiş olup; ölçekte yer almakta olan sorular, iş ile ilişki, güvenilirlik, sorumluluk, etkileşim, organizasyon, fiziki koşullar, iklim, eğlence ve nezaket alt boyutlarından oluşmaktadır.

Araştırmada kullanılan motivasyon ölçeği Herzberg'in Çift Faktör Teorisi baz alınarak İnce (2003) tarafindan hazırlanmış olup, Karaboğa'nın (2007) araştırmasında geliştirilerek kullanılan sorulara dayanmaktadır. Bu kapsamda kullanılan ölçekte Herzberg'in Çift Faktör Teorisine göre motivasyon unsurları işin kendisiyle ilgili olanlar (işin içeriği, ilerleme imkânları, gelişme imkânları, sosyal statü, takdir edilme) ve iş dışı olanlar (fiziki çalışma koşulları, iş arkadaşları ile ilişkiler, iş güvencesi, ücret, yönetici davranışı) olmak üzere iki ana kategoride toplam 10 boyut kapsamında değerlendirilmektedir. Ölçekte yer alan ifadeler 5'li Likert ölçeğinde olup, toplam 35 ifadenin 24'ü olumlu olup kalan 11 'i olumsuzdur.

Hizmet içi eğitim kalite algısı genel güvenilirliği 0,902 bulunmuştur. Motivasyon ölçeği genel güvenilirliği 0,885 ; işin kendisi ile ilgili motivasyon unsuları boyutunun güvenilirliği 0,879 ; iş dışı motivasyon unsurları boyutunun güvenilirliği 0,890 olarak bulunmuştur. Elde edilen Cronbach's Alpha değerlerinin yüksek ve yeterli olduğu görülmüştür.

\section{Verilerin İstatistiksel Analizi}

Araştırmada elde edilen veriler SPSS (Statistical Package for Social Sciences) for Windows 17.0 programı kullanılarak analiz edilmiştir. Verileri değerlendirirken tanımlayıcı istatiksel metotlar (Sayı, Yüzde, Ortalama, Standart 

Algısı ile Motivasyon Düzeyleri Arasindaki IIlişki: İstanbul Bölgesinde Bir Araştırma

Sapma) kullanılmıştır. Araştırmanın bağımlı ve bağımsız değişkenleri arasındaki ilişki Pearson korelasyonu, etki ise regresyon analizi ile test edilmiştir. Elde edilen bulgular $\% 95$ güven aralığında, $\% 5$ anlamlılık düzeyinde değerlendirilmiştir.

Araştırmada kullanılan Likert ölçeği için kişilerin verilen önermelerle ilgili görüşlerini, çok olumludan çok olumsuza kadar sıralanan seçeneklerden belirtmeleri istenmiştir. Buna göre; (5) kesinlikle katılıyorum, (4) katılıyorum, (3) kararsızım, (2) katılmıyorum, (1) kesinlikle katılmıyorum şeklinde bir ölçek kullanılmıştır. Ölçek sonuçları 5.00-1.00=4.00 puanlık bir genişliğe dağılmışlardır. Bu genişlik beşe bölünerek ölçeğin kesim noktalarını belirleyen düzeyler belirlenmiştir.

\section{E. Bulgular ve Yorumları}

$\mathrm{Bu}$ bölümde araştırma probleminin çözümü için, araştırmaya katılan konaklama işletmesi kat hizmetleri departmanı çalışanlarından ölçekler yoluyla toplanan verilerin analizi sonucunda elde edilen bulgular yer almaktadir. Elde edilen bulgulara dayalı olarak açıklama ve yorumlar yapılmıştır.

\section{E.1. Örneklem Grubunun Demografik Özelliklerine İlişkin Bulgular}

Hizmet içi eğitimleri verildiği saptanan konaklama işletmelerinin kat hizmetleri departmanında çalışan 110 kişiye gerçekleştirilen anketlerde, çalışanların yaşlarına göre dağılımına bakıldığında 48'i $(\% 43,6) 18-25$ yaş, 36'sı (\%32,7) 26-30 yaş, 12'si $(\% 10,9)$ 31-35 yaş, 14'ü $(\% 12,7)$ 36-40 yaş olarak dağıtılmaktadır. Cinsiyete göre dağılımına bakıldığında ise 24'ünün $(\% 21,8)$ kadın, 86'sının $(\% 78,2)$ erkek olduğu görülmektedir. Çalışma yılına göre dağılım 62 kişinin $(\% 56,4) 2$ y1l, 34 kişinin $(\% 30,9) 3$ yıl, 14 kişinin $(\% 12,7)$ ise 4 y1l olarak gerçekleşmektedir. Çalışanlarının görevlerine göre 18 'i $(\% 16,4)$ şef, 36's1 $(\% 32,7)$ idari personel, 56 ’sı $(\% 50,9)$ kat personeli olarak saptanmıştır.

Konaklama işletmesi çalışanlarının katıldığ 1 hizmet içi eğitim sayısına göre 14'ü (\%12,7) 1 kez, 18'i (\%16,4) 2 kez, 42'si (\%38,2) 4 kez, 36's1 (\%32,7) 5 kez ve üzeri olarak dağılmaktadır. Konaklama işletmesi çalışanlarının katıldığ hizmet içi eğitim türü değişkenine göre 40 ' $1(\% 36,4)$ işe alıştırma eğitimi, 48 'i $(\% 43,6)$ yönetici gözetiminde eğitim, 22'si (\%20) diğer olarak eğitim seçeneklerini değerlendirmiştir.

\section{Ortalamaları}

\section{E.2. Hizmet İçi Eğitim Kalite Algısı ve Motivasyon Düzeylerinin}

Tablo 1. Hizmet İçi Eğitim Kalite Algısı ve Motivasyon Düzeylerinin Ortalamaları

\begin{tabular}{|l|l|l|l|l|l|}
\hline & $\mathrm{N}$ & Ort. & SS & Min. & Mak. \\
\hline $\begin{array}{l}\text { İşin Kendisi İle İlgili Motivasyon Unsurları } \\
\text { Kaynaklı Motivasyon Düzeyi }\end{array}$ & 110 & 3,469 & 0,568 & 1,620 & 4,190 \\
\hline $\begin{array}{l}\text { İş Dışı Motivasyon Unsurları Kaynaklı Motivasyon } \\
\text { Düzeyi }\end{array}$ & 110 & 3,431 & 0,490 & 2,420 & 4,000 \\
\hline Hizmet İçi Eğitim Kalite Algısı & 110 & 3,944 & 0,515 & 2,030 & 4,400 \\
\hline
\end{tabular}

Araştırmaya katılan çalışanların hizmet içi eğitim kalite algısı ve motivasyon düzeylerinin ortalamaları incelendiğinde, "işin kendisi ile ilgili motivasyon unsurları kaynaklı motivasyon düzeyi" ortalamasının yüksek $(3,469 \pm$ 0,568), "iş dışı motivasyon unsurları kaynaklı motivasyon düzeyi” ortalamasının 
yüksek $(3,431 \pm 0,490)$, "hizmet içi eğitim kalite algısı" ortalamasının yüksek $(3,944 \pm 0,515)$ düzeyde olduğu görülmektedir.

\section{E.3. Hizmet İçi Eğitim Kalite Algııı ve Motivasyon Düzeylerinin Aralarındaki İliş̧kinin Korelasyon Analizi ile İncelenmesi}

Tablo 2. Hizmet İçi Eğitim Kalite Algısı ile İşin Kendisi İle İlgili Motivasyon Unsurları Kaynaklı Motivasyon Düzeyi Korelasyon Analizi

\begin{tabular}{|c|c|c|c|}
\hline & & $\begin{array}{c}\text { İşin Kendisi İle İlgili } \\
\text { Motivasyon Unsurları } \\
\text { Kaynaklı Motivasyon Düzeyi }\end{array}$ & $\begin{array}{l}\text { Hizmet İçi Eğitim } \\
\text { Kalite Algısı }\end{array}$ \\
\hline \multirow{3}{*}{$\begin{array}{l}\text { İşin Kendisi İle İlgili } \\
\text { Motivasyon Unsurları } \\
\text { Kaynaklı Motivasyon } \\
\text { Düzeyi }\end{array}$} & $\mathrm{r}$ & 1,000 & $0,642 * *$ \\
\hline & $p$ & - & 0,000 \\
\hline & $\mathrm{N}$ & 110 & 110 \\
\hline \multirow{3}{*}{$\begin{array}{l}\text { Hizmet İçi Eğitim Kalite } \\
\text { Algısı }\end{array}$} & $r$ & $0,642 * *$ & 1,000 \\
\hline & $\mathrm{p}$ & 0,000 & - \\
\hline & $\mathrm{N}$ & 110 & 110 \\
\hline
\end{tabular}

Hizmet içi eğitim kalite algısı ile işin kendisi ile ilgili motivasyon unsurları kaynaklı motivasyon düzeyi arasında istatistiksel açıdan anlamlı ilişki bulunmuştur $(\mathrm{r}=0,642 ; \mathrm{P}=0,000<0,05)$. Buna göre hizmet içi eğitim kalite algıs1 arttıkça işin kendisi ile ilgili motivasyon unsurları kaynaklı motivasyon düzeyi artmaktadir.

Tablo 3. Hizmet İçi Eğitim Kalite Algısı ile İş Dışı Motivasyon Unsurları Kaynaklı Motivasyon Düzeyi Korelasyon Analizi

\begin{tabular}{|c|c|c|c|}
\hline & & $\begin{array}{l}\text { İş Dışı Motivasyon Unsurları } \\
\text { Kaynaklı Motivasyon Düzeyi }\end{array}$ & $\begin{array}{l}\text { Hizmet İçi Eğitim } \\
\text { Kalite Algısı }\end{array}$ \\
\hline \multirow{3}{*}{$\begin{array}{l}\text { İş D1şı Motivasyon } \\
\text { Unsurları Kaynaklı } \\
\text { Motivasyon Düzeyi }\end{array}$} & $r$ & 1,000 & $0,594 * *$ \\
\hline & $\mathrm{p}$ & - & 0,000 \\
\hline & $\mathrm{N}$ & 110 & 110 \\
\hline \multirow{3}{*}{$\begin{array}{l}\text { Hizmet İçi Eğitim Kalite } \\
\text { Algis1 }\end{array}$} & $\mathrm{r}$ & $0,594 * *$ & 1,000 \\
\hline & $\mathrm{p}$ & 0,000 & - \\
\hline & $\mathrm{N}$ & 110 & 110 \\
\hline
\end{tabular}

Hizmet içi eğitim kalite algısı ile iş dışı motivasyon unsurları kaynaklı motivasyon düzeyi arasındaki korelasyon istatistiksel açıdan anlamlı bulunmuştur $(r=0,594 ; p=0,000<0,05)$. Buna göre hizmet içi eğitim kalite algısı arttıkça, iş dış1 motivasyon unsurları kaynaklı motivasyon düzeyleri artmaktadır.

\section{Etkisi}

E.4. Hizmet İçi Eğitim Kalite Algısının Motivasyon Düzeylerine

Tablo 4. Hizmet İçi Eğitim Kalite Algısı ile İşin Kendisi İle İlgili Motivasyon Unsurları Regresyon Analizi

\begin{tabular}{|c|c|c|c|c|c|c|c|}
\hline Bağımlı Değişken & $\begin{array}{l}\text { Bağımsız } \\
\text { Değișken }\end{array}$ & $\beta$ & $\mathbf{t}$ & $\mathbf{p}$ & $\mathbf{F}$ & $\begin{array}{c}\text { Model } \\
\text { (p) }\end{array}$ & $\mathbf{R}^{2}$ \\
\hline $\begin{array}{llll}\text { İșin } & \text { Kendisi İle } & \text { İlgili }\end{array}$ & Sabit & 0,676 & 2,093 & 0,039 & \multirow[t]{2}{*}{75,899} & \multirow[t]{2}{*}{0,000} & \multirow[t]{2}{*}{0,407} \\
\hline $\begin{array}{lr}\text { Motivasyon } & \text { Unsurları } \\
\text { Kaynaklı } & \text { Motivasyon } \\
\text { Düzeyi } & \end{array}$ & $\begin{array}{lr}\text { Hizmet } & \text { İçi } \\
\text { Eğitim } & \text { Kalite } \\
\text { Alg1s1 } & \end{array}$ & 0,708 & 8,712 & 0,000 & & & \\
\hline
\end{tabular}

Hizmet içi eğitim kalite algısı ile işin kendisi ile ilgili motivasyon unsurları arasındaki ilişkiyi belirlemek üzere yapılan regresyon analizi istatistiksel olarak anlamlı bulunmuştur $(\mathrm{F}=75,899 ; \mathrm{p}=0,000<0,05)$. İşin kendisi ile ilgili 

Algısı ile Motivasyon Düzeyleri Arasindaki İlişki: İstanbul Bölgesinde Bir Araştırma

motivasyon unsurları düzeyinin belirleyicisi olarak hizmet içi eğitim kalite algısı değişkenleri ile ilişkisinin (açıklayıcılık gücünün) olduğu görülmüştür $\left(\mathrm{R}^{2}=0,407\right)$. Çalışanların hizmet içi eğitim kalite algısı düzeyi işin kendisi ile ilgili motivasyon unsurlarına kaynaklı motivasyon düzeyini artırmaktadır $(\beta=0,708)$.

Tablo 5. Hizmet İçi Eğitim Kalite Algıısı ile İş Dışı Motivasyon Unsurları Kaynaklı Motivasyon Düzeyi Regresyon Analizi

\begin{tabular}{|c|c|c|c|c|c|c|c|}
\hline Bağımlı Değişken & $\begin{array}{l}\text { Bağımsız } \\
\text { Değişken }\end{array}$ & $\beta$ & $\mathbf{t}$ & $\mathbf{p}$ & $\mathbf{F}$ & $\begin{array}{c}\text { Model } \\
\text { (p) }\end{array}$ & $\mathbf{R}^{2}$ \\
\hline İs D1s1 Motivasyon & Sabit & 1,206 & 4.125 & 0,000 & \multirow[t]{2}{*}{58,863} & \multirow[t]{2}{*}{0,000} & \multirow[t]{2}{*}{0,347} \\
\hline $\begin{array}{l}\text { Unsurları Kaynaklı } \\
\text { Motivasyon Düzeyi }\end{array}$ & $\begin{array}{lr}\text { Hizmet } & \text { İçi } \\
\text { Eğitim } & \text { Kalite } \\
\text { Algıs1 } & \end{array}$ & 0,564 & 7,672 & 0,000 & & & \\
\hline
\end{tabular}

Hizmet içi eğitim kalite algısı ile iş dışı motivasyon unsurları arasındaki ilişkiyi belirlemek üzere yapılan regresyon analizi de istatistiksel olarak anlamlı bulunmuştur. ( $\mathrm{F}=58,836 ; \mathrm{p}=0,000<0,05)$. İş dış1 motivasyon unsurları düzeyinin belirleyicisi olarak hizmet içi eğitim kalite algısı değişkenleri ile ilişkinin (açıklayıcılık gücünün) güçlü olduğu görülmüştür $\left(\mathrm{R}^{2}=0,347\right)$. Çalışanların hizmet içi kalite eğitim algısı düzeyi, iş dışı motivasyon unsurlarını kaynaklı motivasyon düzeyini artırmaktadır $(\beta=0,564)$.

\section{Sonuç}

Hizmet içi eğitim, gelişim göstermekte olan konaklama sektöründe, işletmelerin başarıya ulaşmalarını ve bunu sürdürülebilir kılmaları adına önem gösteren konulardan biri olarak ön plana çıkmaya başlamıştır. Verimlilik ve kalitenin sağlanabilmesi için uygulamaların bir gereklilikten çok zorunluluk haline geldiğini görülmektedir. Çalışan motivasyonu ise işletmelerin başarı sağlamasında ana rolü oynayan etmenlerden biridir. Konaklama sektöründe iyi hizmet verilebilmesi adına, işletmeler öncelikli olarak kendi çalışanlarını motive etmeli; böylece etkin ve etkili üretim süreçlerinin uygulanması olası kılınmalıdır.

Yapmış olduğumuz çalışmada İstanbul bölgesinde yer almakta olan konaklama işletmelerinde çalışan ve hizmet içi eğitime tabi tutulmuş kat hizmetleri departmanı çalışanlarının, hizmet içi eğitim kalite algısı ile Frederick Herzberg'in Çift Faktör Teorisi çerçevesinde iş ile ilgili motivasyon unsurları ve iş dışı motivasyon unsurları kaynaklı motivasyon düzeyleri ilişkisi ve ilişki gücü incelenmiştir.

Korelasyon analizleri incelendiğinde konaklama işletmelerinde çalışmakta olan kat hizmetleri personelinin hizmet içi eğitim kalite algısı ile hem iş ile ilgili motivasyon unsurları, hem de iş dışı motivasyon unsularına bağlı motivasyon düzeyleri arasında doğrusal bir ilişki olduğu belirlenmiştir. Ayrıca regresyon analizlerinde hizmet içi eğitim kalite algısının, iş ile ilgili motivasyon unsurları ve iş dışı motivasyon unsurlarına göre motivasyon düzeylerini artırdığ bulgusu ortaya konmuştur.

Hizmet içi eğitim çalışmalarının, çalışanların davranışlarında olumlu etki yaptığı (Örücü, Kanbur ve Kanbur, 2007) ve motivasyon ve kişilerin gelişimi ile işgücü verimliliğinin ve iş tatmininin arttırılmasında kat hizmetleri bölümü yöneticilerinin kat hizmetleri bölümü çalışanlarını zaman zaman eğitim 
programlarına almaları gerektiği (Kozak, 2011: 27) bilinmektedir. Çalışma kapsamında önerilmekte olan $\mathrm{H}_{1}$ ve $\mathrm{H}_{2}$ hipotezleri kabul edilmiş olup; Elde edilen bulgular, daha önceki çalışmalarda (Akıncı, 2002; Uslu ve diğerleri, 2013; Sezgin ve Ünlüönen, 2011) elde edilmiş olan sonuçları destekler niteliktedirler. Yine otel işletmelerinde çalışan iş görenlerin iş doyumlarının eğitim düzeylerine göre farklılaştığ (Elbeyi ve Pelit (2010); beşy1ldızlı otel işletmelerinde çalışan iş görenlerde alınan hizmet içi eğitimin kurumda örgütsel bağl1lığı arttırdığı ve daha sık yapılması gerektiği (Tayfun, Palavar ve Çöp 2010), çalışmalarıyla uygunluk göstermektedir.

Yöneticiler belirtilen motivasyon unsurlarını dikkate alarak hareket etmeli ve çalışanlarının motivasyon seviyelerini yüksek tutmayı amaçlamalıdırlar. Araştırmamızın sonuçlarında da belirtildiği üzere motivasyon artırıcı bir aktivite olarak hizmet içi eğitim uygulamalarının planlanması ve doğru uygulamalar ile sağlanması, konaklama işletmelerinde çalışanlar üzerinde olumlu etkiler yaratacak; böylece işletmeler başarılarını sürdürülebilir kılacaklardır.

Çalışmamız spesifik olarak konaklama işletmelerinde bir departmana yönelmekte, bu sebepten ötürü kısitlamalar içermektedir. Bundan sonra gerçekleştirilecek olan çalışmalarda, evrenin genişletilerek turizm açısından yoğunluk göstermekte olan diğer destinasyonlara da yayılması ve departman sayısının artırılması ile çalışmanın kapsamı geliştirilebilecektir.

KAYNAKÇA

AKINCI, Zeki (2002), "Turizm Sektöründe İşgören İş Tatminini Etkileyen Faktörler: Beş Yıldızlı Konaklama İşletmelerinde Bir Uygulama", Akdeniz İ. İ. B. F. Dergisi, 4, 1-25.

AKSU, A. Akın (2005), "Defining Training Needs of Five-Star Hotel Personnel: An Application in the Antalya Region of Turkey", Managerial Auditing Journal, 20(9), 945-953.

AKTAŞ, Ahmet (2002), Turizm İşletmeciliği ve Yönetimi, Antalya: Azim Matbaa, 2. Baskı.

ALKIŞ, Hüseyin ve Yüksel ÖZTÜRK (2009), "Otel İşletmelerinde Motivasyon Faktörleri Üzerine Bir Araştırma", Elektronik Sosyal Bilimler Dergisi, 8(28), 212-236.

AYTAÇ, Tufan (2000), "Hizmet İçi Eğitim Kavramı ve Uygulamada Karşılaşılan Sorunlar", Milli Ĕ̈itim Dergisi, 147, 66-69.

BİLGiN, Kamil Ufuk, AKAY, Aslı, KOYUNCU, H. Emre, ve E. Çetin HAŞAR (2007), Yerel Yönetimlerde Hizmet İ̧̧i Ĕ̆itim, Ankara: TEPAV.

BOELLA, Michael J. ve Steven GOSS-TRUNER (2005), Human Resource Management in the Hospitality Industry: An Introductory Guide", Oxford: Elsevier Butterworth-Heinemann.

CLEMENZ, Candici E. (2001), Measuring Perceived Quality of Training in the Hospitality Industry, Yayınlanmamış Doktora Tezi, Virginia: Virginia Polytechnic Institute and State University.

HAYES, David K. Ve Jack D. NINEMEIER (2008), Human Resources Management in the Hospitality Industry, New Jersey : John Wiley \& Sons, Inc..

HARRIS, Kimberley J. (1995), "Training Technology in the Hospitality Industry: a Matter of Effectiveness and Efficiency", International Journal of Contemporary Hospitality Management, 7(6), 24-29.

İNCE, Özlem (2003), İs Tatminine Etki Eden Başlıca Faktörler ve Uygulamadan Bir Örnek, Yayınlanmamış Yüksek Lisans Tezi, İstanbul: Marmara Üniversitesi Sosyal Bilimler Enstitüsü.

KARABOĞA, Meral, (2007), Avcılar İlçesi Otä̈ğretim Kurumları Yöneticilerinin Motivasyonlarının Çalı̧̧an (Öğretmen) Motivasyonu Üzerine Etkisi, Yayınlanmamış Yüksek Lisans Tezi, İstanbul: T.C. Beykent Üniversitesi Sosyal Bilimler Enstitüsü. 
H. Tanrıverdi \& M. A. Şahin / Konaklama İşletmelerinde Kat Hizmetleri Çalışanlarının Hizmet İçi Ĕ̈itim Kalite Algısı ile Motivasyon Düzeyleri Arasındaki Illişki: İstanbul Bölgesinde Bir Araştırma

KORKMAZ, Sezer, TEMIZKAN, Saadet Pınar ve Rahman TEMIZKAN (2010), "Profesyonel Turist Rehberlerinin Turizm Pazarlamasındaki Rolü ve Hizmet İçi Eğitim Seminerlerinin Pazarlama Açısından İçerik Analizi”, Ticaret ve Turizm Eğitim Fakültesi Dergisi, 1, 133149.

KOZAK, Meryem Akoğlan, (2011), “Otel işletmelerinde Kat Hizmetleri Yönetimi”, 8. Baskı, Detay Yayıncılık, Ankara.

LUNDBERG, Christine, GUDMUNDSON, Anna ve Tommy D. ANDERSSON (2009), "Herzberg's Two Factor Theory of Work Motivation Tested Empirically on Seasonel Workers in Hospitality and Tourism", Tourism Management, 30, 890-899.

NICKSON, Dennis (2007), Human Resource Management for the Hospitality and Tourism Industries, Oxford: Elsevier Butterworth-Heinemann.

OTTENBACHER, Michael (2008) "Employee Management and Innovation". D. V. Tesone, A. Pizam, Handbook of Hospitality Human Resouces Management içinde, First Edition, Oxford: Elsevier Butterwort-Heinemann.

ÖRÜCÜ, Edip, KANBUR Engin ve KANBUR Aysun, (2007). Kamu Kuruluşlarında Verilen Hizmet İçi Eğitim Faaliyetlerinin Çalışanların Verimliliğine Etkisi”, Mevzuat Dergisi, Yıl 10, Say1: 115, http://www.mevzuatdergisi.com/2007/07a/02.htm (12/11/2014).

ÖZTÜRK, Mustafa ve Süleyman SANCAK (2007), "Hizmet İçi Eğitim Uygulamalarının Çalışma Hayatına Etkileri”, Journal of Yasar University, 2(7), 761-794.

ÖZTÜRK, Yüksel ve Hüseyin ALKIŞ (2011), "Konaklama İşletmelerinde Çalışanların İş Tatmininin Ölçülmesi Üzerine Bir Araştırma”, ZKÜ Sosyal Bilimler Dergisi, 7(14), 437460.

ÖZTÜRK, Yüksel ve Kadir SEYHAN (2005), "Konaklama İşletmelerinde Sunulan Hizmet Kalitesinin Artırılmasında İşgören Eğitiminin Yeri ve Önemi”, Ticaret ve Turizm Eğitim Fakültesi Dergisi, 1, 121-140.

PEHLIVAN, İnayet (1997), “Örgütsel ve Bireysel Gelişme Aracı Olarak Hizmet İçi Eğitim”, Amme Iddaresi Dergisi, 30(4), 105-120.

PELİT Elbeyi ve ÖZTÜRK, Yüksel. (2010), "Otel İşletmeleri İşgörenlerinin İş Doyum Düzeyleri: Sayfiye ve Şehir Otel İşletmeleri İşgörenleri Üzerinde Bir Araştirma” İşletme Araştırmaları Dergisi, 2 (1), 43-72.

SEZGIN, E. Köksal ve Kurban ÜNLÜÖNEN (2011), "Mutfak Personelinin Hizmet İçi Eğitiminin Örgütsel Bağlılık Ve İş Tatminine Etkisi Üzerine Bir Uygulama”, İşletme Araştırmaları Dergisi, 3(2), 3-16.

TAYFUN, Ahmet, PALAVAR, Karabey, ÇÖP, Serdar, (2010) İşgörenlerin Eğitim ve Örgütsel Bağlılık Düzeyleri Arasındaki İlişki: Belek Bölgesindeki Beş Yıldızlı Otel İşletmelerinde Bir Araştırma" İşletme Araştırmaları Dergisi, 2(4), 3-18.

USLU, Abdullah, KUTUKIZ, Doğan ve Hüseyin ÇEKEN (2013), "Otel İşletmelerinde Çalışan Personelin Aldığı Hizmet İçi Eğitimin Verimliliğe Etkisi”, Verimlilik Dergisi, 2, 101-116.

WALKER, John R. ve Jack E. MILLER (2010), Supervision in the Hospitality Industry: Leading Human Resources, New Jersey: John Wiley \& Sons, Inc., Sixth Edition.

WHILTELAW, Paul A., BARRON, Paul, BUULTJENS, Jeremy, CAIRNCROSS, Grant ve Michael DAVIDSON (2009), Training Needs of the Hospitality Industry, Australia: CRC for Sustainable Tourism. 